\title{
Aflatoxin Contamination Level of Different Crops in Ethiopia
}

\author{
Aserse Yenasew \\ Biology, Food Science and Nutrition Division, Ethiopia Institute of Agricultural Research, Addis Ababa, Ethiopia
}

Email address:

asresyenasew@gmail.com

\section{To cite this article:}

Aserse Yenasew. Aflatoxin Contamination Level of Different Crops in Ethiopia. International Journal of Bioorganic Chemistry. Vol. 4, No. 1, 2019, pp. 42-46. doi: 10.11648/j.ijbc.20190401.16

Received: February 16, 2019; Accepted: March 22, 2019; Published: April 18, 2019

\begin{abstract}
This review paper was conducted to show the current status of aflatoxin contamination level of some selected crop commodities. Different data sources were collected from January, 2018 up to February, 2019 from published, unpublished and other scientific research reports. The results reported by different authors indicated that total aflatoxin, AFB1, AFB2, AFG1 and AFG2 are the aflatoxin types that contaminate groundnut, red pepper, maize, malt barely, sorghum and other types of crop commodities. According to different authors and research reports showed AFB1 is the most common aflatoxin type that contaminates different crops. Based on the review, the current aflatoxin contamination level of some Ethiopian crops were above permissible level according to the FAO/WHO and EU standards. This indicates that most Ethiopia people consume different crops that contaminated by aflatoxin due to lack of awareness about the cause and the effects of aflatoxin. The increment of temperature and moisture content were favorable for the growth of aflatoxigenic fungi. Different authors reported that the moisture and temperature increases, the aflatoxin contamination level of crops also increases.
\end{abstract}

Keywords: Aflatoxin, Aflatoxigenic Fungi, Increment

\section{Introduction}

Aflatoxin is toxic secondary products of mycotoxin produced by certain moulds of the genus aspergillus, pencillium and fusarium. Aspergillus is a large genus of mould which grows at an optimum range of temperature of $28-33^{\mathrm{O}} \mathrm{c}$ and water activity of about $0.83-0.97$. The major fungi that produce aflatoxins are aspergilus flavus, aspergilus nomius and aspergilus parasiticus [1]. These species contaminate various agricultural commodities ether before harvest or at post-harvest stages under favorable conditions of temperature and humidity.

Around 18 types of aflatoxin have been identified [2]. Among these four classes of aflatoxin such as AFB1, AFB2, AFG1 and AFG2 are the most dominant in nature. These aflatoxin distinguished by their fluorescent color under ultraviolet light. Aflatoxin is odorless, tasteless and colorless. Chemically, they are stable in foods and resistant to degradation under normal cooking procedures.

The occurrence of aflatoxin influenced by source of food, specific enzyme of the fungus and favorable environmental conditions such as high moisture content and temperature [3]. Post-harvest contamination can occur during storage if the moisture content is above optimum value [4].

Cereals and its products are the main food for human consumption through the world. Rice, wheat, maize, sorghum and millet are the most important cereal crop in the world. The cereal grains belong to maize, sorghum, millet, rice, wheat and barley is found susceptible to aflatoxin accumulation by aflatoxigenic fungi.

Aflatoxins are a family of toxins which produced from aspergillus fungi that contaminate different foods and feed products in the field, at harvest, and during storage [5]. Aflatoxins are mostly associated with produced in warm and humid regions of agricultural crops like maize, rice, and sorghum, barley, rye, wheat, groundnut, soybean and cotton seed [6]. It also present in cereals, nuts, spices and fruits. Favorable conditions for the contamination of Hot peppers by aflatoxins are atmospheric temperature, humidity, drying and storage conditions [7].

The contamination of agricultural crop and animal products via aflatoxins has great impact on human and animal health and also economic losses. People can be exposed to aflatoxins by consuming plant products, meat and dairy products [8]. Aflatoxin B1 is the most common in food and the most known genotoxic and carcinogenic aflatoxin. Aflatoxin can cause both acute and chronic toxicity in 
humans and animals. Some of the effects of are acute liver damage, liver cirrhosis, and induction of tumours, teratogenic and other genetic effects. The level of AFB1 is much higher than AFB2. This shows that AFB2 is less toxic effect on human and animal health than AFB1 [5]. IARC has classified AFB1 is the group of carcinogenic agent [9]. It causes acute and chronic toxicity [10].

Aflatoxin contamination can also affect agricultural livelihoods in various ways. Aflatoxin can cause crop loss due to low yields, the market value of and uses for a contaminated crop decrease, farm animals can have stunted growth and lower yields of by-products such as milk and eggs and expose to health care costs and smallholder farmer families are mostly likely to consume contaminated crops. The aim of this research review paper was to show the aflatoxin contamination level of aflatoxin susceptible agricultural crop commodities in Ethiopia.

\section{Materials and Methods}

Data sources were collected from January, 2018 through February, 2019. A range of literature sources were used for this review including journal articles, books, book chapters, workshop proceeding, FAO reports, legal documents and unpublished reports were including Ph.D. dissertations as well as MSc thesis. The documents were collected from Ethiopia institute of agricultural research and universities, individual researcher, and from the internet data bases.

\section{Aflatoxin Contamination Levels of Susceptible Crop Commodities}

The aflatoxin contamination level of most agricultural crop commodities that exposed by aflatoxin are groundnut, maize, malt barely and sorghum were listed below.

\subsection{Aflatoxin Contamination Level of Groundnut}

The AFB1, AFB2, AFG1 and AFG2 level were $1.7 \mathrm{ng} / \mathrm{g}-2368 \mathrm{ng} / \mathrm{g}, \quad 0.2 \mathrm{ng} / \mathrm{g}-237 \mathrm{ng} / \mathrm{g}, \quad 102.495 \mathrm{ng} / \mathrm{g} \quad$ and $8.05-96.9 \mathrm{ng} / \mathrm{g}$ respectively as indicated on table 1 . In addition to this, Ayalew indicated that the total aflatoxin levels of groundnut seeds were $5 \mu \mathrm{g} / \mathrm{kg}-250 \mu \mathrm{g} / \mathrm{kg}$ [11]. Similarly, Amare detected total aflatoxin level in groundnut samples and ranged from $5 \mathrm{ppb}-250 \mathrm{ppm}$ in eastern parts of Ethiopia [12]. The lowest aflatoxin level of AFB1, AFB2, AFG1 and AFG2 were recorded on groundnut seed at Fedis, Gurusum, Babile, and Bible districts respectively while the highest aflatoxin level of AFB, AFB2, AFG1, and AFG2 recorded at Fedis.

Table 1. Showed the aflatoxin level of groundnut seed in eastern parts of Ethiopia.

\begin{tabular}{lll}
\hline Districts & Aflatoxin type & Aflatoxin level (ng/g) \\
\hline \multirow{3}{*}{ Babile } & AFB1 & $4.45-1624.5$ \\
& AFB2 & $0.2-88.25$ \\
& AFG1 & LOD \\
& AFG2 & LOD \\
\hline
\end{tabular}

\begin{tabular}{lll}
\hline Districts & Aflatoxin type & Aflatoxin level (ng/g) \\
\hline \multirow{4}{*}{ Darolabu } & AFB1 & $3.05-719.1$ \\
& AFB2 & $0.35-106.9$ \\
& AFG1 & $102.495-398.95$ \\
& AFG2 & $8.05-89.6$ \\
Fedis & AFB1 & $1.7-2368$ \\
& AFB2 & $0.3-237$ \\
& AFG1 & $238-477$ \\
Gurusum & AFG2 & $53-96.9$ \\
& AFB1 & $4.5-682$ \\
& AFB2 & $0.1-35.5$ \\
& AFG1 & 187.1 \\
\hline
\end{tabular}

Source [13]

As indicated on the table 2, the level of AFB1 and AFB2 of groundnut cake in major cities of eastern parts of Ethiopia were $0.7 \mathrm{ng} / \mathrm{g}-158.1 \mathrm{ng} / \mathrm{g}$ and $0.2 \mathrm{ng} / \mathrm{g}-15.3 \mathrm{ng} / \mathrm{g}$ respectively. The lowest levels of AFB1 and AFB2 of groundnut cake were recorded at Haramaya city where as the highest level of AFB1 and AFB2 were recorded at Diredawa city. Besrat and Gebre showed that the mean level of AFB1 of $34.7 \mu \mathrm{g} / \mathrm{kg}$ and $105 \mu \mathrm{g} / \mathrm{kg}$ in samples of groundnut and peanut butter respectively [14].

Table 2. Showed the aflatoxin level of groundnut cake in eastern part of Ethiopia.

\begin{tabular}{lll}
\hline Districts & Aflatoxin type & Aflatoxin levels (ng/g) \\
\hline \multirow{2}{*}{ Babile } & AFB1 & $0.7-39.1$ \\
& AFB2 & $0.2-4.6$ \\
Diredawa city & AFB1 & $1.5-158.1$ \\
& AFB2 & $0.2-15.3$ \\
Haramaya city & AFB1 & LOD \\
& AFB2 & LOD \\
Harar city & AFB1 & LOD \\
& AFB2 & LOD \\
Jijiga city & AFB1 & $2.8-9.4$ \\
& AFB2 & $0.2-0.8$ \\
\hline
\end{tabular}

Source [13]

Chala have been collected different samples from different districts at different storage conditions as well as from the market and analyzed the total aflatoxin level as indicated below on table 3. The highest levels of total aflatoxin of groundnut seeds were recorded at both sampled conditions and different districts. Gurusum distirict was less grain contamination as compared to Babile and Darolabu districts. From Gurusum distirict, a total of 41 groundnut samples were tested for total aflatoxin concentration and 24 samples were positive. However, positive samples from the market and storage houses of this district have higher aflatoxin level than those from Darolabu. Positive samples from the markets of this district had aflatoxin concentration ranging between $16 \mu \mathrm{g} / \mathrm{kg}$ and $10,100 \mu \mathrm{g}$. Aflatoxin concentrations in the positive groundnut samples from the stores varied from 15 $\mathrm{mg} / \mathrm{kg}$ to $5560 \mu \mathrm{g} / \mathrm{kg}$.

At all districts the total aflatoxin levels were above the permissible level of EU $(4 \mu \mathrm{g} / \mathrm{kg}), \mathrm{FAO} / \mathrm{WHO}(15 \mu \mathrm{g} / \mathrm{kg})$. In addition to that Chala have been assessed the total aflatoxin level of different groundnut varieties in southern parts of 
Ethiopia, but the results showed that the total aflatoxin level of groundnut varieties were under permissible level according the EU and FAO standards limits [15]. Generally, different researcher's reports indicated that aflatoxin contamination of groundnut occurs above safe level in eastern part of Ethiopia which is higher in EU and FAO/WHO limits.

Table 3. Indicated the aflatoxin concentration in groundnut samples from eastern parts of Ethiopia.

\begin{tabular}{|c|c|c|c|c|c|}
\hline Districts & Number of samples analyzed & Positive samples (\%) & Negative samples (\%) & Store $(\mu \mathrm{g} / \mathrm{kg})$ & Markets $(\mu \mathrm{g} / \mathrm{kg})$ \\
\hline Babile & 39 & $34(87.2)$ & $5(12.8)$ & $157-11,900$ & $15-9770$ \\
\hline Darolabu & 40 & $35(87.5)$ & $5(12.5)$ & $15-1980$ & $15-4940$ \\
\hline Gursum & 41 & $24(58.5)$ & $17(41.5)$ & $15-5560$ & $16-10,100$ \\
\hline
\end{tabular}

Source: Chala et al 2013[16]

\subsection{Aflatoxin Contamination Level of Maize Aflatoxin}

The aflatoxin contamination levels in maize, recorded from minimum to maximum incidence of different types of aflatoxins. According to different researcher reports showed that the mean total aflatoxin level of maize samples in Ethiopia is $3.13 \mu \mathrm{g} / \mathrm{kg}$.

Amare showed the total aflatoxin level of maize that has been collected around Adama, Diredawa and Ambo was < $5 \mu \mathrm{g} / \mathrm{kg}$ [17]. According to Masersha reported the mean total aflatoxin levels of $18.38 \mu \mathrm{g} / \mathrm{kg}$ and $43.43 \mu \mathrm{g} / \mathrm{kg}$ for pre harvest and post-harvest maize respectively [18]. In addition to that Maseresha indicated the pre harvest maize of AFB1, AFB2, AFG1, and AFG2 were $5 \mu \mathrm{g} / \mathrm{kg}$, $1.17 \mu \mathrm{g} / \mathrm{kg}, 10.10 \mu \mathrm{g} / \mathrm{kg}$ and $2.10 \mu \mathrm{g} / \mathrm{kg}$ respectively and the results of post-harvest maize samples of AFB1, AFB2, $\mathrm{AFG} 1$, and AFG2 were $9.86 \mu \mathrm{g} / \mathrm{kg}, 7.2 \mu \mathrm{g} / \mathrm{kg}, 18.11 \mu \mathrm{g} / \mathrm{kg}$, and $8.14 \mu \mathrm{g} / \mathrm{kg}$ respectively.

The level of AFB1 at Babile, Kersa, and Haramaya were ranges between $5 \mu \mathrm{g} / \mathrm{kg}-16.126 \mu \mathrm{g} / \mathrm{kg}, 5 \mu \mathrm{g} / \mathrm{kg}-33 \mu \mathrm{g} / \mathrm{kg}$ and $5 \mu \mathrm{g} / \mathrm{kg}-11.826 \mu \mathrm{g} / \mathrm{kg}$ respectively underground pit storage conditions [19]. Other finding shows that $4.1 \mu \mathrm{g} / \mathrm{kg}$ of total aflatoxin was detected from maize in Ethiopia [17]. Similarly, AFB1 contamination in maize in South Ethiopia was $22.72 \mu \mathrm{g} / \mathrm{kg}[20]$.

\subsection{Aflatoxin Contamination Level of Sorghum}

The northern parts of Ethiopia farmers were interviewed for their knowledge regarding aflatoxin contamination in their areas. The total aflatoxin contamination level of sorghum sampled above ground storage and underground storage systems for less than 12 months, 1-2 years, and greater than two years storages period's indicated below.

Table 4. Shows the total aflatoxin content of under different storage conditions and periods.

\begin{tabular}{|c|c|c|c|c|c|c|}
\hline Storage condition & Above ground & & & Under ground & & \\
\hline Storage period & $<12$ months & $1-2$ years & $>2$ years & $<12$ months & $1-2$ years & $>2$ years \\
\hline Total aflatoxins $(\mu \mathrm{g} / \mathrm{kg})$ & $16.59-183.16$ & $46.48-177.33$ & $44.27-210.53$ & $11.44-344.26$ & $65.17-247.92$ & 21.47 \\
\hline
\end{tabular}

Source [21]

This reviewed showed total aflatoxin contamination level ranges from $11.44 \mu \mathrm{g} / \mathrm{kg}-344 \mu \mathrm{g} / \mathrm{kg}$ and the mean total aflatoxin values of $23.85 \mu \mathrm{g} / \mathrm{kg}$ [21]. Ayalew also reported a small proportion (6\%) of Sorghum field samples to be contaminated with AFB1 up to $26 \mu \mathrm{g} / \mathrm{kg}[11]$.

Table 5. Indicates the AFB1 contamination level of underground pit storage conditions of sorghum grains at different temperature and relative humidity.

\begin{tabular}{|c|c|c|c|c|}
\hline \multicolumn{2}{|l|}{ Districts } & Babile & Kersa & Haramaya \\
\hline \multicolumn{2}{|c|}{ The mean AFB1 freshly harvested sorghum grain $(\mu \mathrm{g} / \mathrm{kg})$} & 684 & $\begin{array}{l}624 \\
1157\end{array}$ & $\begin{array}{l}907 \\
1193\end{array}$ \\
\hline \multicolumn{2}{|c|}{ The mean AFB1 level of stored sorghum grain $(\mu \mathrm{g} / \mathrm{kg})$} & 1302 & & \\
\hline \multicolumn{2}{|c|}{ The mean moisture content freshly harvested sorghum grain $(\%)$} & $12.7 \pm 0.5$ & $13.9 \pm 0.6$ & $12.1 \pm 0.3$ \\
\hline \multirow{2}{*}{$\begin{array}{l}\text { The mean of underground pit temperature } \\
\text { and relative humidity }(\%)\end{array}$} & Temperature & $281 \pm 2.0$ & $24.6 \pm 1.5$ & $25.5 \pm 1.9$ \\
\hline & Relative humidity & $77.9 \pm 4.7$ & $65.9 \pm 3.3$ & $71.3 \pm 4.5$ \\
\hline
\end{tabular}

Source [19]

The optimum temperature for the growth of mould producing fungi were in the range of about 25-30oc at stored grain [22]. Drying agricultural products especially cereals until the moisture content reaches $10-13 \%$ were critical because it creates less favorable condition for fungal growth [23]. As shown on table 5, AFB1 level increased in stored sorghum grain when compared to freshly harvested grain. This is due to the higher moisture content and high storage temperature condition of the sorghum grain because both moisture and temperature are the key environmental factors that influence the growth of fungi and aflatoxin contamination levels. In addition to this, Chala also reported maximum and minimum levels of AFB1 sorghum grains samples collected from farmer's stores in various locations of south, east and northwest Ethiopia were $62.5 \mu \mathrm{g} / \mathrm{kg}$ and $29.5 \mu \mathrm{g} / \mathrm{kg}$ respectively [24]. 


\subsection{Aflatoxin Contamination Level of Malt Barely}

Extensive survey has been performed in different parts of Ethiopia with regard of aflatoxin contamination in malt barely. Different authors have reported that total aflatoxin contamination level of traditional malt barely in Ethiopia ranges from $0.27 \mu \mathrm{g} / \mathrm{kg}-23.6 \mu \mathrm{g} / \mathrm{kg}$ as well as the local and imported industrial malt barely from $3.67 \mu \mathrm{g} / \mathrm{kg}-5.06 \mu \mathrm{g} / \mathrm{kg}$ [25]. This review result indicated the traditional malt barely more contaminated than industrial malt barely. The traditional malt barely aflatoxin contamination levels were due to poor pre harvest and post -harvest management.

\section{Conclusion}

Generally, most reports indicates that the total aflatoxins contamination level of major grains such as groundnut, maize and sorghum occurs above the safe level according to international standards in many parts of Ethiopia. So we should give greater emphasis on aflatoxins contamination because it has greater impact on human and animal health, food safety, markets and income and also occurs in diverse foods and animal feeds. Aflatoxins, potent carcinogens in humans and animals mainly get into the biological system via diets. The human health impacts resulting from acute and chronic aflatoxins exposure adds losses in cost of illness, contributing to the cycle of poverty which may contribute to further ill-health. However, several methods are available for reducing the adverse impact of aflatoxins such as proper agronomic and crop management practices, competitive biological control using non-aflatoxins producing strains of A flavus and others. The review paper results contribute to understand the cause and effects of aflatoxins on humans and animals, to know the appropriate control measures and also used to create awareness on the aflatoxigenic fungi and associated mycotoxins. The proper management methods that reduce the fungi infection and level of aflatoxins contamination are drying properly to safe moisture levels after harvesting and storing under appropriate conditions.

\section{Acknowledgements}

I acknowledge the research authors regarding aflatoxin contamination level reported by the earlier journal authors and express my appreciation for permitting to use the required data from their journals.

\section{References}

[1] Guo B, Chen Z, Lee RD, Secully BT (2008). Drought stress and pre harvest aflatoxin contamination in agricultural commodity.

[2] Saleemullah Al, Iqtidar AK, Hamidullah S (2006). Aflatoxin contents of stored and artificially inoculated cereals and nuts.

[3] Schmale DG (1998). Mycotoxins in crops: A threat to human and domestic animal health. Virginia polytechnic institute and state university, Blacksburg, Vagary P. Munkvoldlowa state university, Ames.

[4] Herrman T (2006). Mycotoxins in feed grains and ingredients grain science and industry Kansas state university agricultural experiment station and cooperative extension service department of grain science and industry.

[5] G. F. P. Piva, Fabio G, Amedeo P, Andrea P (1995). Detoxification methods of aflatoxins. A review.

[6] Burch DGS, Rosell C (2001). The role of mycotoxins in pmws-factor or Fiction.

[7] Cokosyler N (1999). Farkh yontemelerle kurutulan kir. mizi biberlerde aspergillus flavus gelisimi ye aflatoksin olusumunun incelenmesi, Gida

[8] Brera C, Debegnach F, Desantis B, Lafrate E, Pannuni E, Berdini C, Prantera E, Gregori E, Miraglia M. Ochratoxin A in Cocoa and chocolate products from the Italian market: occurance and exposure assessment. Food control 2011; 22:1663-1667.

[9] IARC (international agency for the research on cancer), (2002). Monograph on the evaluation of carcinogenic risks to humans. Lyon: IARC press.

[10] Lizarraga-Paulin EG, Moreno- Martinez E, Mirandacastrosp. (2011). Aflatoxins and their impact on human and animal health: An emerging problem. Aflatoxins- Biochemistry and molecular biology, Ramon G, Guevara-Gonzalez (ED), ISBN: 978-953307-395-8, Intec.

[11] Ayalew A, Fehrmann H, Lepschybeck R, Abate D (2006). Natural occurrence of mycotoxins in stable cereals from Ethiopia.

[12] Amare A, Dawit A, Mengistu H (1995). Mycoflora, aflatoxins and resistance of groundnut cultivars from eastern Ethiopia.

[13] Abdi M, Alemayehu C, Mashilla D, Chemeda F, David AH, Sobolev, Victor S, and Arias, r. s.," aspergillus and aflatoxins in groundnut (Arachis hypogeal) and groundnut cake in Eastern Ethiopia'(2016). Publications from USDA-ARS/UNL faculty. 1809 .

[14] Besrat A, Gebre P (1981). A preliminary study on the aflatoxin content of selected Ethiopia foods. Ethiop med j. 19: 47-52.

[15] Chala A, Mohammed A, Ayalew A, Skinnes H (2012). Natural occurrence of aflatoxins in groundnut (Arachis hypogaeal L.) form eastern Ethiopia. Food control. In press.

[16] Chala A, Mohammed A, Ayalew A, Skinnes H (2013). Natural occurance of aflatoxins in groundnut (Arachis hypogaealL.)From eastern Ethiopia. Food control.30:602-605.

[17] Amare A (2010). Mycotoxins and surface and internal fungi of maize from Ethiopia.

[18] Masresha A, Negero G, Geremew T (2016). Aspergillus species and aflatoxin contamination of pre and post-harvest maize grain in west Gojjam, Ethiopia.

[19] Wondemineh T, Amare A, Alemayehu C, Mahillaa D (2016). Aflatoxin B1 and total fumonisin contamination and their producing fungi in fresh and stored sorghum grain in east hararghe, Ethiopia.

[20] Alemu T, Birhanu G, Azerefgne F, Skinners H (2008). Evidence for mycotoxin contamination of maize in southern Ethiopia. 
[21] Geremew T (2015). Study on aspergillus species and aflatoxin levels in sorghum (sorghum bicolor L.) stored at different period and storage system in kewet districts, Northern Shewa, Ethiopia.

[22] Dubale B, Solomon A, Geremew B, Sethumadhava RG, Waktole S (2014). Mycoflora of grain (Zea mayes) stored in traditional storage containers (gombisiaa and sacks) in selected woredas of Jimma zone, Ethiopia.

[23] Hell K, Fandohan P, Bandyopadhyay R, Kiewnick S, Sikora R,
Cotty PJ (2005). Fungal and mycotoxin contamination of Nigerian foods and feeds. Hell K, Fandohan P, Bandyopadhyay R, Kiewnick S, Sikora R, Cotty PJ. 2005.

[24] Chala A, Taye W, Ayalew A, Krska R, Sulyok M, Logrieco A (2014). Multimycotoxin analysis of sorghum (sorghum bicolor L. Moench) and finger millet (Eleusine coracana L. Garten) from Ethiopia.

[25] Addis A (2017). Comparative study of aflatoxins level between traditional and industrial barely malt in Ethiopia. 